ISSN 2413-0877 Volume 1 (2015)

The 1st International Symposium on Aquatic Product Processing 2013

\title{
EVALUATION AND IMPLEMENTATION HACCP OF FROZEN TUNA SAKU
}

\author{
Welma Pesulima and Ovie Ningsih \\ Departement of Fishery Processing Technology, Artha Wacana \\ Christian University Kupang - Indonesia \\ e-mail : pesulimawelma@yahoo.com; ovieningsih@gmail.com
}

\begin{abstract}
Research about evaluation and implementation HACCP document of frozen tuna saku product Focus at HACCP document evaluation, used descriptive qualitative method and quantitative test from level histamine value in fresh tuna was received and pathogen bacterium at fresh water and also presentage of level improve with audited result of implementation from revised HACCP document. Revised of HACCP document frozen tuna saku, to show two critical control point the first at phase recieving fresh tuna as raw material with a purpose to histamnie eliminated, histamine value representing hazard potencial by applying critical limit control at refrigeration process use ice so that center of fish temperature remain at range $0-4,4^{\circ} \mathrm{C}$, and second critical control point in the butchering or dehaeding phase with a purpose to pathogen bacteria Escerichia coli, Coliform, and Salmonella spp eliminated which possible could happened from used fresh water without treatment. Audit result of revised HACCP document of frozen tuna saku implementation quantitatively its at level improve about $89 \%$ compared to HACCP document before revised that is still at level $62 \%$, this level matter is make-up of in the case of document implementation revised by HACCP team. Level improve have to monitoring implementation HACCP document to make assurance of quality and security from frozen tuna saku, that has been export product.
\end{abstract}

Keywords: audit, critical control point(s), critical limit, frozen tuna saku, HACCP, histamine

\section{INTRODUCTION}

HACCP Concept represent of food security management method having the character of systematic and relied on principles which have been recognized, to be addressed to identify hazard which possibility earn happened in each step in supply chain of food, operation action placed to prevent appearance of hazard. HACCP is acronym used to preventive system by operation control of critical point able to happened during process production ( hazard analysis critical control point).

HACCP also represent food security management system which have proven and relied on preventive action. Identify situation about hazard which possibly will appear in course of, required operation action will be able to be placed properly. This matter to ensure that food security is true managed effectively and to degrade depend on traditional method like examination and inspection. According to Indonesia National Standard (SNI 01-48521998), HACCP ( Hazard Analysis Critical Control Points) is apparatus to assess hazard and specify focused operation system at prevention more than take on most test of final product only ( testing to end product) or preventive system for the security of food. HACCP can be applied entire food chain primary product come up with final consumption and its applying have to be guided by evidence scientifically to risk health for human being. System 
of HACCP not such a food security guarantee which without risk ( zero-risk) but designed to minimize food security from hazard risk.

Fishery product is export commodity and also marketed by home affairs require special attention in the case of handling security so that the product save to consumers. The reason of fishery product either was dumped by Europe, Japan and also America, because of carelessness and poor handling and process. First step taken is changed regulation and published regulation by Indonesia Minister of Marine Affairs and Fisheries Number. PER. 01 /MEN/2007 about Operation of Best Quality System And Security Fishery Product later on innovated with regulation by Indonesia Minister of Marine Affairs and Fisheries Number . PER.19/MEN/2010 About Operation of Best Quality System and Security Fishery Product of Each regulation special to every business unit fishery of individual goodness and also company obliged to apply HACCP method better and downright so that guarantee product quality and security ( Poernomo, 2010). Prerequisite program as reference for implementation HACCP system by applying hygienic, procedure prerequisite working which confessed nationally and also international like seen on Table 1.

Table1. Prerequisite program applying hygienic, procedure for HACCP implementation system

\begin{tabular}{|c|c|c|}
\hline \multicolumn{3}{|c|}{ Prerequisite program = Good Hygienic Practices (GHP) } \\
\hline $\begin{array}{l}\text { As conditions early in } \\
\text { applying of HACCP at } \\
\text { food sector becoming } \\
\text { compulsion according to } \\
\text { Codex General Principles } \\
\text { of Food Hygiene, the } \\
\text { appropriate Codex } \\
\text { Codes of Practices, and } \\
\text { appropriate food safety } \\
\text { legislation (CAC, 2001) }\end{array}$ & $\begin{array}{l}\text { Early Conditions executie } \\
\text { which prepared condition } \\
\text { before and during } \\
\text { applying of HACCP } \\
\text { because very important } \\
\text { representing for food } \\
\text { security (WHO, 1999) }\end{array}$ & $\begin{array}{l}\text { Applying overall of } \\
\text { procedure performed } \\
\text { within factory ( processing } \\
\text { unit) or recognized with } \\
\text { Good Manufacturing } \\
\text { Procedures } \\
\text { explaining operationally } \\
\text { entire all condition which } \\
\text { specified as reference } \\
\text { applying HACCP system } \\
\text { (NACMCF, 1998) }\end{array}$ \\
\hline
\end{tabular}

Hazard analysis and critical control point ( HACCP) system and also guidance applying which adopted from CAC / RCP 1-1969,Rev.3 ( 1997), and special for frozen tuna standard adapted by frozen tuna loin SNI01-4104.1-2006. 
Tabel 2 National quality standard frozen tuna loin (SNI 01-4104.1-2006)

\begin{tabular}{|c|c|c|c|}
\hline & Analysis & Measure & Condition \\
\hline a. & Minimum Sensory & Number (1-9) & 7 \\
\hline \multirow[t]{5}{*}{ b. } & Microbe Contaminate & & \\
\hline & Total Plate Count & coloni/gram & $\operatorname{Max} .5 \times 10^{5}$ \\
\hline & Eschericia coli & NPN / gram & Max. $<2$ \\
\hline & Salmonella spp & NPN/gram & Negative \\
\hline & Vibrio cholera & NPN / gram & Negative \\
\hline \multirow[t]{5}{*}{ c. } & Chemical & & \\
\hline & $\mathrm{Hg}$ & $\mathrm{Mg} / \mathrm{kg}$ & Max. 1 \\
\hline & $\mathrm{Pb}$ & $\mathrm{Mg} / \mathrm{kg}$ & Max. 0.4 \\
\hline & Histamine & $\mathrm{Mg} / \mathrm{kg}$ & Max. 100 \\
\hline & Cadmium (Cd) & $M g / k g$ & Max. 0.5 \\
\hline \multirow[t]{2}{*}{ d. } & Physical & & \\
\hline & Central temp. & ${ }^{\circ} \mathrm{C}$ & -18 \\
\hline e. & Parasit & Tail & Max. 0 \\
\hline
\end{tabular}

Purpose of research to evaluate manual HACCP by frozen tuna saku product and how to re-design of document for implementation.

\section{MATERIAL AND METHODS}

This research represent qualitative descriptive, with evaluating manual HACCP frozen tuna product accompanied of other supporter document in contact with standard procedure had by processing unit to export.

Method survey by conducting perception, and interview directly with employment and processing manager with 12 step how to design manual HACCP :

1. listing question accomodating needed data collecting (questionnaire comprise every step process production like in flow chart of frozen tuna saku)

2. evaluating manual HACCP with HACCP team

3. conduct and repair manual HACCP special with team HACP of frozen tuna saku using compilation 12 step

4. conducting describe product, represent a list which comprising final product type which included in concept of HACCP, taken data cover the name of product, raw material, path process product, packaging material, storage, specification and lable, target usage of product

5. identifying and target usage of product, product to be controlled through system HACCP beforehand have to be determined by plan its use. This step done by taking second data from the form of identifying usefulness of product which there are in HACCP plan.

6. compilation by flow chart processing congelation pocket with aim to depict product operational phase or sequence start from depository acceptance phase until in chilled depository room.

7. conducting verification frozen tuna saku processing flow chart, this step conducted with checked about processing flow chart which have been produce by redesign flow chart on known HACCP team. 
8. identifying and hazard analysis, step hazard analyse represent gathering process and assessment of information concerning situation and hazard earn the happening of hazared to determine such affecting reality to food security specially frozen tuna saku and have to handle in plan of HACCP. This Step conducted by identifying and hazard, taking to product security able to happened in course done production, and also needed to precaution control potential risk or hazard which hazardous.

9. identify CCP (Critical Control Point) the step where identifyed every process path causing the existence of real hazard have to identify furthermore for the surely of step included in CCP or not CCP. This step conducted to judge CCP by using tree decision or decision making diagram which relate at CAC 2003).

10. critical boundary is maximum value or minimum which must be controlled in each CCP.This step have conducted by taking critical boundary data which used by which there are in HACCP plan. Technique to take the data use critical boundary parameter which become $\mathrm{CCP}$ like temperature, time, amount of additional materials, $\mathrm{pH}$, and others.

11. specifying monitoring procedure, monitoring procedure consist of perception activity, examination or measurement conducted to assess CCP stay in critical boundarys which specified or do not. This step will specifying corrective action, corrective action represent procedure which must be executed when skipped over critical boundary. This action mentioned in the table form operation of CCP.

12. verification done, that is verification action represent method, procedure, examination anA way of other assessment beside monitoring to determine as according to HACCP plan. ThE step conducted by making step in the form of method, procedure and or examination of which done if skipped over critical boundary.

13. Record-keeping procedure and documentation, lock efficacy the way system of HACCP that is accuracy of record-keeping system (keeping record) made conducting implementation manual HACCP of frozen tuna saku process according to result of guidance evaluation of HACCP.

14. make an audit of HACCP implementation frozen tuna product doing examination attendance of histamine raw material of content and Escerichia coli at used as water is supporter of procedure implementation data according to guidance document of HACCP. 
Step of research will looking at the Figure 1.

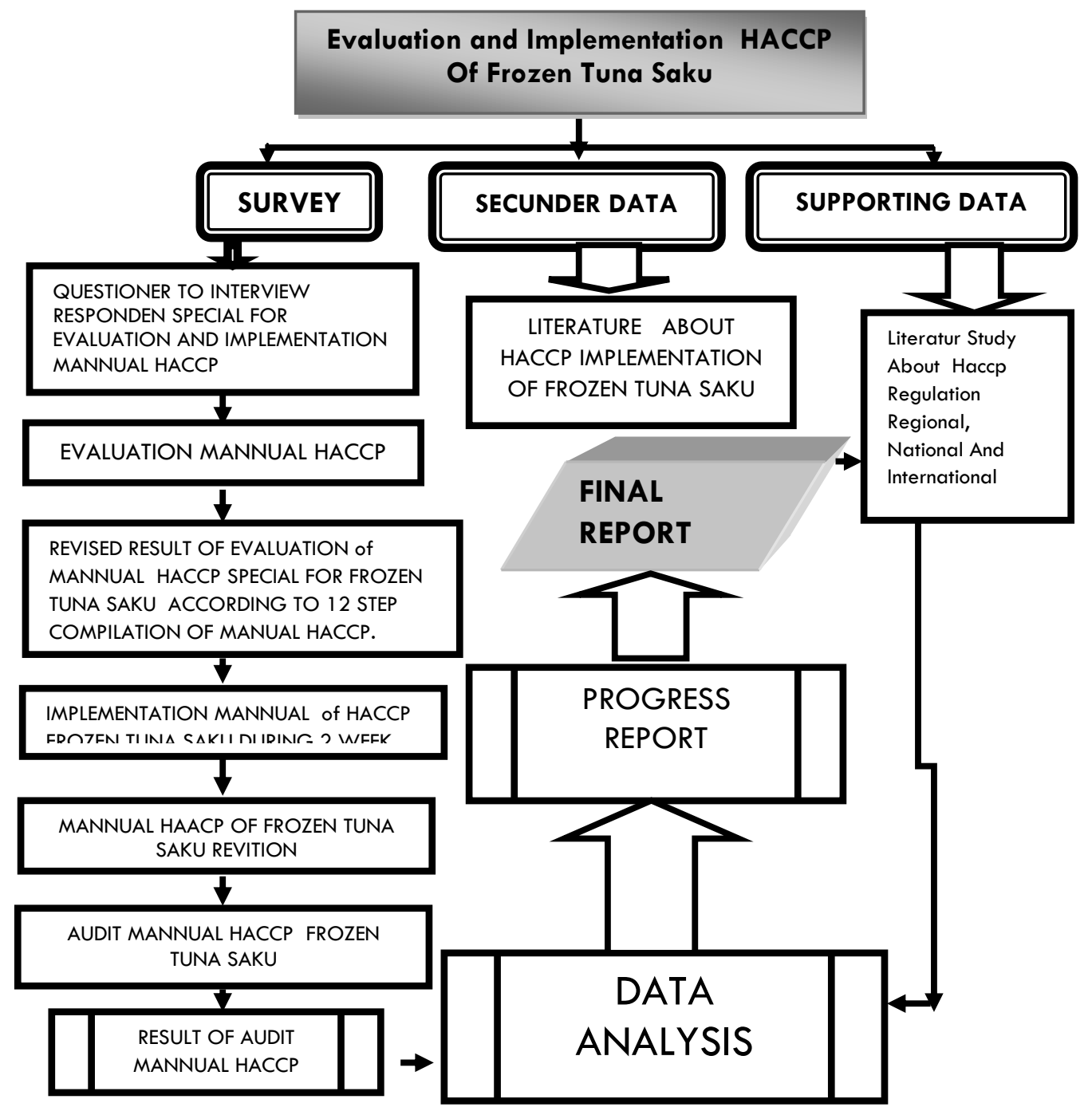

Figure 1 Roadmap of Research

\section{RESULT AND DISCUSSION}

\section{Frozen Tuna Saku}

Frozen tuna saku product which yielded from tuna raw material (Yellow fin tuna or Thunnus albacore) with size $20 \mathrm{kgs}$ up, AAA quality with red flesh color (description sensory) fresh, texture elastic, aroma of typical fresh fish, coherent tail and fin of strength at fish body, sweet taste, hereinafter fish head off, gill and gutted then fish cutting become 4 or part of loin, skinless, boneless, dark meat off, formed to become "saku" product ( product of the size : $12-18 \mathrm{~cm} \times 5-8 \mathrm{~cm} \times 2,5-3 \mathrm{~cm})$, weight $0,5-1 \mathrm{lbs}(277 \mathrm{gr}-454 \mathrm{gr}$ per pieces) packaging in 
vacuum plastic by IVP ( packed vacuum individually), arranged in pan later then frozen in air blast freezer $(A B F)-40^{\circ} \mathrm{C}$ during $6-8$ hour so that temperature center fish $-18^{\circ} \mathrm{C}$ or below.

\section{Before Evaluation HACCP Document}

Before HACCP document evaluated in this research, have owned document of HACCP to made for one manual HACCP for a few product for example fresh loin, frozen tuna saku, frozen tuna "saku" $\mathrm{CO}$, compiled in one manual HACCP document, admission filling of checklist to every step in HACCP have been conducted even guidance of HACCP have experienced to revise. Fishery processing unit result have owned with $B$ value (GOOD) from Certificate Eligibility of Processing from Indonesia Minister of Marine Affairs and Fisheries. One Flow chart for several fishery product before audited manual HACCP as look at Figure 2.

\section{After Reviced HACCP Document.}

After manual HACCP document to improve by flow chart processing frozen tuna saku product, verification which have and analyzed to use tree decision (CAC,2003). Found 2 CCP that acceptance standard fresh tuna upon which and usage of water at the time of butchering, because using water which direct contact with tuna fish (raw material).

First CCP ( critical control point's) acceptance raw material closely related with temperature center fish suspected if exceeding $4,4^{\circ} \mathrm{C}$ hence will influence histamine rate which mounting at tuna which fish type of scombroidae, in general highest histamine there are at meat dark at depository condition of fish above temperature $4^{\circ} \mathrm{C}$, so that expenditure of depository and dark meat with temperature below $4^{\circ} \mathrm{C}$ matter which must be conducted in the case of handling of standard fresh tuna upon which frozen tuna saku

Histamine is a naturally occurring endogenous substance in the human body which is derived from the decarboxylation of the amino acid histidine. Histamine may also be present in certain foods containing free histidine, and is generated by certain bacteria during spoilage and fermentation of fish. Endogenous histamine has important physiological functions related to local immune responses, gastric acid secretion, and neuromodulation. Histamine-rich foods may cause food intolerance in sensitive individuals and histamine contamination in fish and fish products may cause food poisoning (Taylor 1986). Histamine rate at fresh fish reside in 0,1 $\mathrm{mg} / 100$ gram and will mount sharply till reach $90-100 \mathrm{mg} / 100 \mathrm{gram}$ during $12 \mathrm{hr}$ when let at room temperature, when let at temperature $20-25^{\circ} \mathrm{C}$ during 10 day will mount till $95.000 \mathrm{mg} / 100 \mathrm{gr}$. At temperature $0^{\circ} \mathrm{C}$ tuna still dined competent till 15 day because rate of histamine not yet mounted from $5 \mathrm{mg} / 100 \mathrm{gram}$ (Anonymous 2000). 
Receiving Raw Material (recieving fresh tuna)

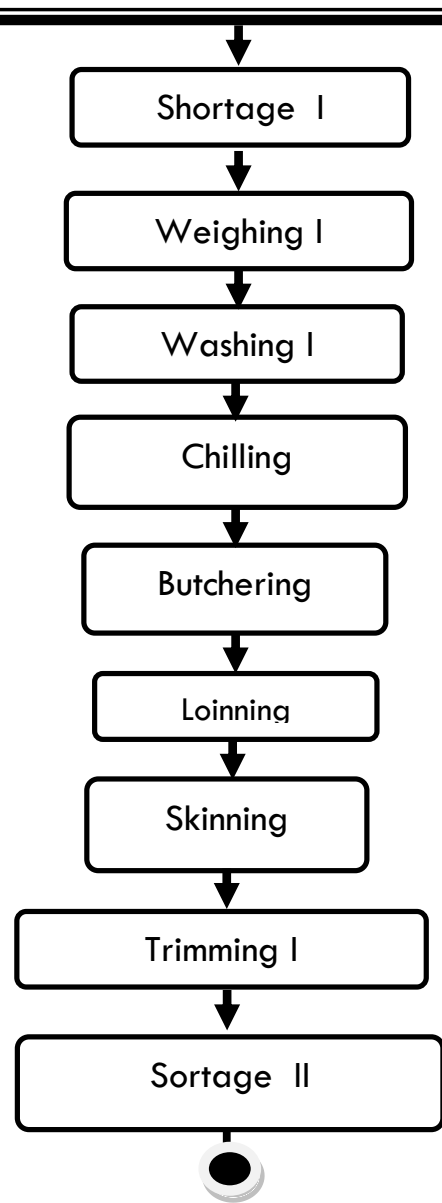

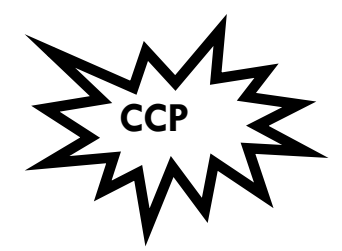




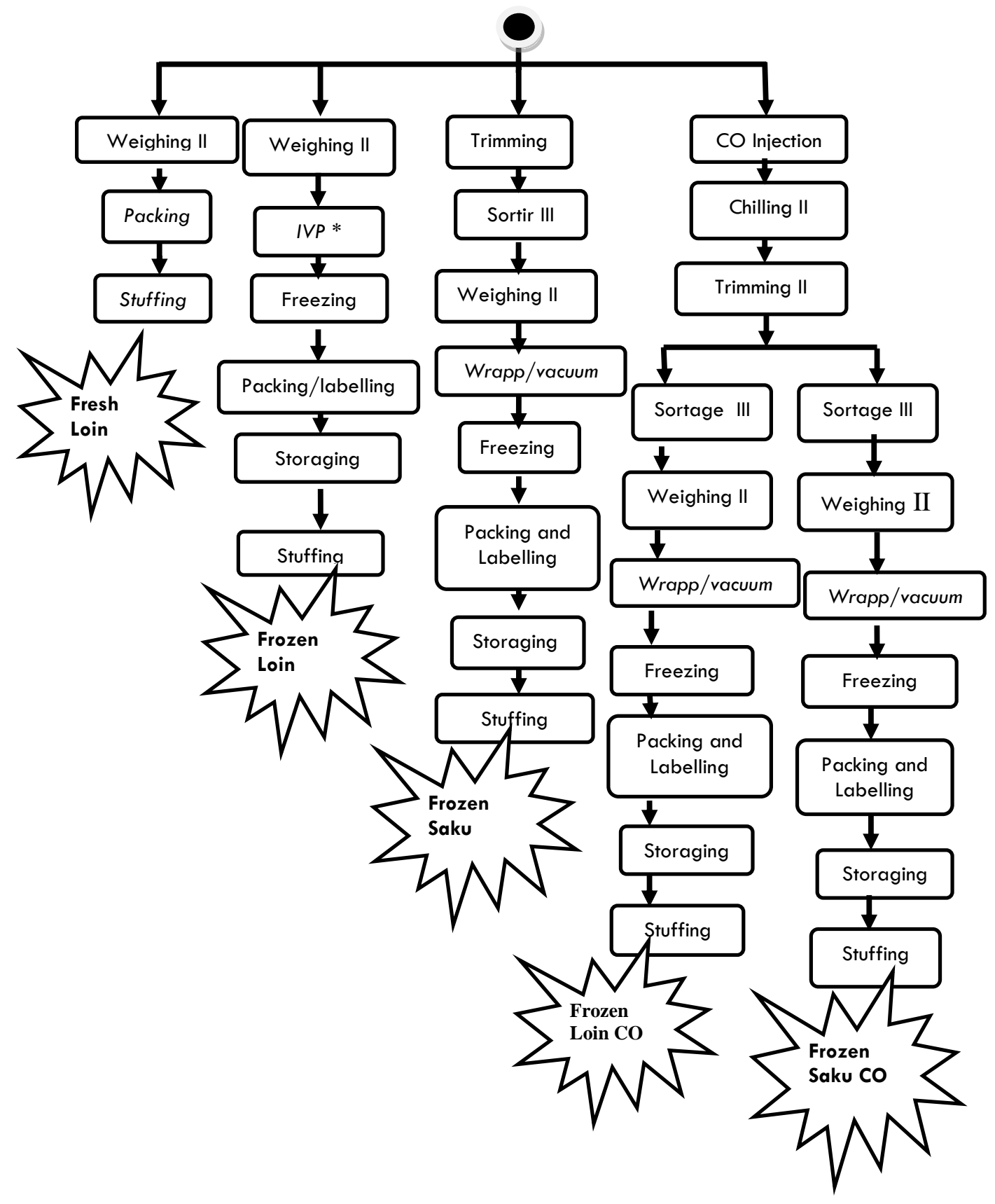

Figure 2. Flow chart frozen product 


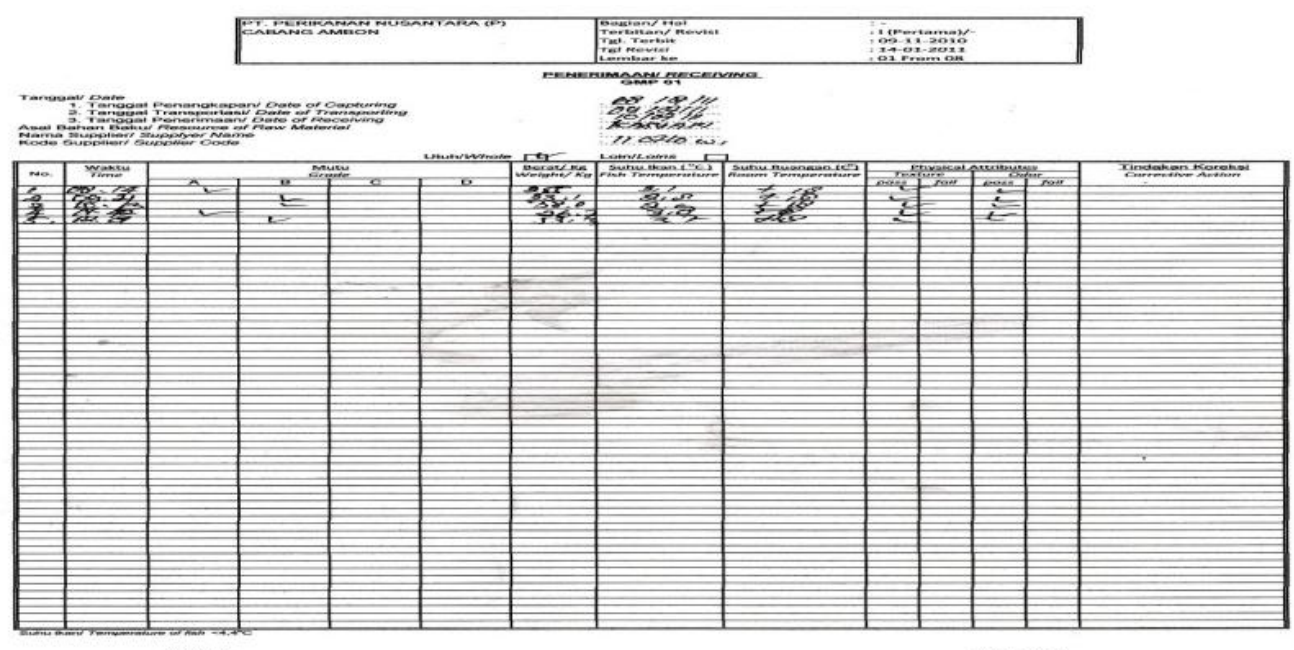

Figure 3. Checklist CCP before revised HACCP Document

Bacterium producer enzyme of histidine decarboxylase earn diinaktif immediately degrade temperature below/under $4^{\circ} \mathrm{C}$ when freezing direct and dead fish, this matter that happened bacterium pursued by propagation it but when product melted by hence activities bacterium will still going on. In the reality not merely histamine representing single factor in the case of cause of poisoned but is also influenced by amen other biogenic so that strengthen its toxin effect, poisoned earn happened at dose $50 \mathrm{gram} / \mathrm{kg}$ or $50 \mathrm{ppm}$.

Histamine fresh fish tuna content at the most $1 \mathrm{mg} / 100 \mathrm{gram}$, above temperature $10^{\circ} \mathrm{C}$ or room temperature $\left(25-30^{\circ} \mathrm{C}\right)$ rate of histamine leap till $1 \mathrm{gram} / 100 \mathrm{gram}$. For decrease opportunity to histamine rate increase at tuna raw material to yield tuna saku frozen hence designed by procedure in the form of checklist in the case of usage ice periodically to take care of fish center temperature. While second point critical at usage of controlled water by giving chlorine at source of used water with correct concentration so that growth of Escherichia coli can be pursued. For the food security product hence standard of E.Coli according to SNI 2006 frozen tuna loin product do not exceed 2 APM/100 ml or according to FDA for product result fishery do not exceed 100 colony $/ \mathrm{ml}$ usage of water the cleanness have experienced process of treatment use and also chlorine of ozonisation very suggested by doing phase produce where product come into contact with direct with water, and or at sanitizing process equipments and room and also employees remain to be paid attention better and good record-keeping so that easy to traced.

Result of implementation all manual HACCP document made an audit of during 2 week give picture which positive enough, where entire employees which commit there one HACCP execute operation to critical point able critical unsafely frozen tuna saku product which yielded. Result of implementation and evaluation decanted in flow chart Figure 3 and result of examination to $E$. coli of used water direct than 3 well exist in processing unit location and 
content of Histamin before and after evaluation can be seen at Tables 1, 2,3. Result of the Test of Histamine within measure consume human being while for E.Coli is negative.

Audit result revised manual HACCP document of frozen tuna saku implementation quantitatively at level improve about $89 \%$ compared to manual HACCP document before revised that is still at level $62 \%$, this level matter is make-up of in the case of document implementation revised by HACCP team. Level improve have to monitoring implementation manual HACCP document to make assurance of quality and security from frozen tuna saku, that has been export product.

Table 3 Histamine content at raw material ( fresh tuna fish ) and frozen tuna saku

\begin{tabular}{lcc}
\hline \multicolumn{1}{c}{ Product } & $\begin{array}{c}\text { Value Histamine (ppm) } \\
\text { before revised manual } \\
\text { HACCP }\end{array}$ & $\begin{array}{c}\text { Value Histamine } \\
\text { (ppm) } \\
\text { manual HACCP }\end{array}$ \\
$\begin{array}{l}\text { Fresh tuna yellow fin } \\
\text { Frozen tuna saku (Center Temp. }\end{array}$ & 11.8 & 12 \\
$-19^{\circ} \mathrm{C}$ ) & 7 & 6,4 \\
\hline
\end{tabular}

Table 4 Water quality in processing frozen tuna saku before revised manual HACCP document

\begin{tabular}{|c|c|c|c|c|c|c|c|}
\hline \multirow[t]{2}{*}{$\begin{array}{l}\text { Sample } \\
\text { code }\end{array}$} & TPC & Colifor & E.coli & $\begin{array}{c}\text { Type of Test } \\
\text { Salmonella }\end{array}$ & V.cholera & $\mathrm{pH}$ & $\mathrm{T}^{\circ} \mathrm{C}$ \\
\hline & $\begin{array}{l}\text { Method } \\
\text { Test SNI } \\
01- \\
2332.3- \\
2006\end{array}$ & $\begin{array}{l}\text { Method } \\
\text { Test } \\
\text { SNI } 01 \text { - } \\
2332.3 \\
-2006\end{array}$ & $\begin{array}{l}\text { Method } \\
\text { Test SNI } \\
01- \\
2332.3- \\
2006\end{array}$ & $\begin{array}{l}\text { Method } \\
\text { Test SNI } \\
01- \\
2332.3- \\
2006\end{array}$ & $\begin{array}{l}\text { Method } \\
\text { Test SNI } \\
01- \\
2332.3- \\
2006\end{array}$ & & \\
\hline Source 1 & $<2500$ & $<2.0$ & $<2.0$ & Negative & Negative & 7.19 & 28 \\
\hline Source 2 & $<2500$ & $<2.0$ & $<2.0$ & Negative & Negative & 7.11 & 27 \\
\hline Source 3 & $<2500$ & $<2.0$ & $<2.0$ & Negative & Negative & 7.40 & 28 \\
\hline
\end{tabular}

\section{Flow chart and verification}

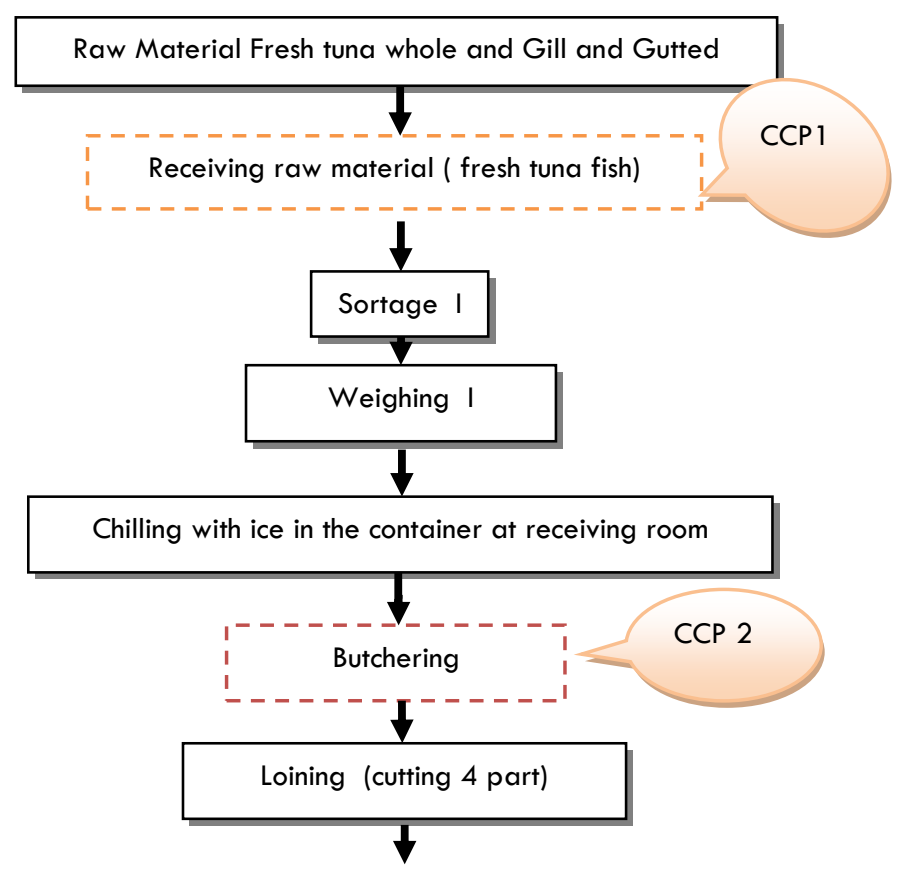




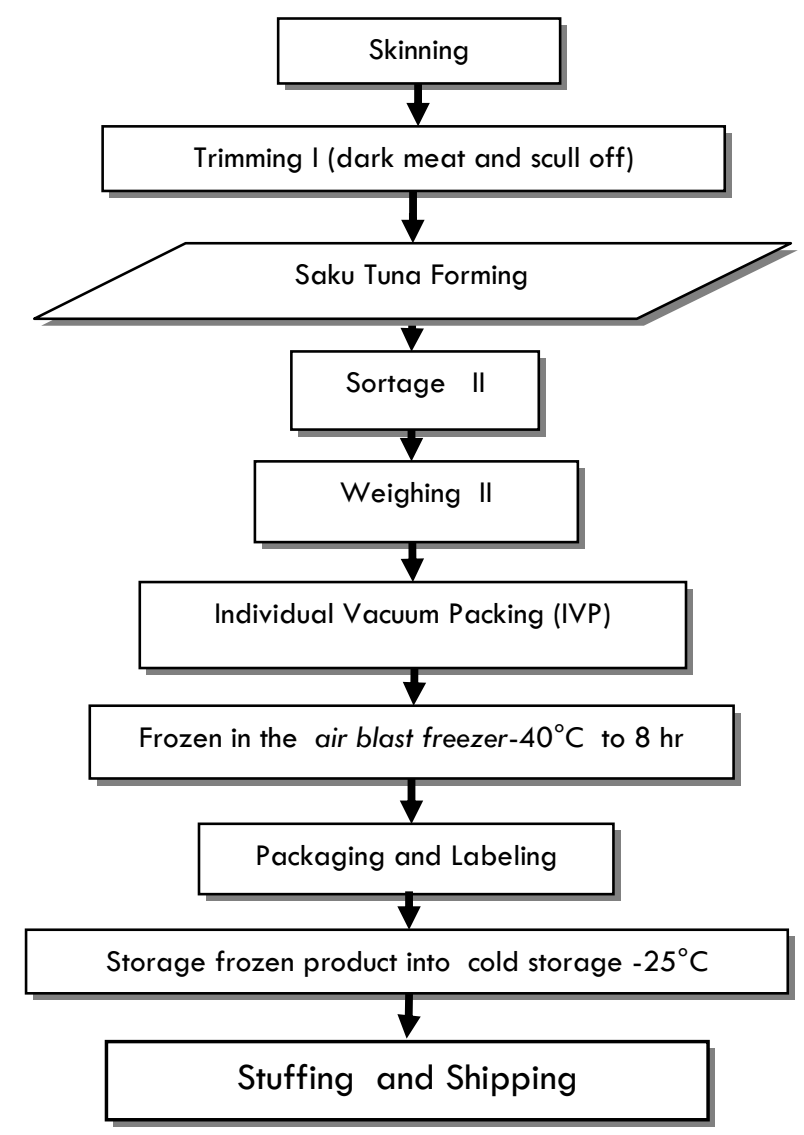

Table 5 Water quality in processing frozen tuna saku after revised manual HACCP document

\begin{tabular}{llllllll}
\hline & \multicolumn{7}{c}{ Type of Test } \\
\cline { 2 - 8 } & TPC & Coliform & E.coli & Salmonella & V.cholera & \\
& Method & Method & Method & Method & Method & & \\
Sample Test & Test & Test SNI & Test & Test SNI & Test SNI & pH & $\mathrm{T}^{\circ} \mathrm{C}$ \\
& SNI 01- & $01-$ & SNI 01- & $01-$ & $01-$ & & \\
& $2332.3-$ & $2332.3-$ & $2332.3-$ & $2332.3-$ & $2332.3-$ & & \\
& 2006 & 2006 & 2006 & 2006 & 2006 & & \\
\hline Source 1 & $<2000$ & $<2.0$ & $<2.0$ & Negative & Negative & 7.18 & 27 \\
Source 2 2 & $<2000$ & $<2.0$ & $<2.0$ & Negative & Negative & 7.05 & 27 \\
Source 3 3 & $<2000$ & $<2.0$ & $<2.0$ & Negative & Negative & 7.30 & 28 \\
\hline
\end{tabular}

Compared standard quality of fresh water in the package as Nasional Indonesia Standard or SNI $01-3553$ 2006:
TPC
E.coli
Salmonella spp
:Max $1.0 \times 10^{5} \mathrm{coloni} / \mathrm{ml}$
$:$ Max $<2.0 \mathrm{NPN} / 100 \mathrm{~m}$
: Negative per $100 \mathrm{ml}$

\section{CONCLUSION}

Result evaluation of manual HACCP document show entirety 12 phase compilation HACCP for frozen tuna saku product of revised found by CCP (Critical Control Points) phase acceptance fresh tuna fish for raw material because relating to attendance histamine as source of hazardous which must eliminated and at butchering phase because washed fresh fish was direct than well, so that opportunity of crossed contamination as source of hazard 
have to be controlled. Result implementation and audition manual HACCP document frozen tuna saku product revised show applying manual HACCP have always watched so that do not happened mistake or misunderstanding in the case of admission check and write available checklist as a whole and special checklist for the operation critical point at every step conducted process.

Frozen tuna saku product with quality hence suggested every processing unit obliged to provide treatment water to get the quality best water, and manual HACCP document to every yielded to be product to be dissociated to facilitate monitoring various arising out hazardous during production process because that is relation with food security and quality export fishery product.

\section{Acknowledgment}

We wish to thank PT.Perikanan Nusantara - Ambon Branch, for the research year 20112012.

\section{REFERENCES}

Anonymous,2010,An introduction to HACCP for Fish Processors Asean Network of Fisheries post Harvest Technology Centres, Singapore.

Anonymouse, 2010., Product Hand Book, Tuna Saku Booklet, web buklet, Island Brand, Island Lobster LTD., Miami

Attanasova et al., 2008., Micribiological Quality of sushi From sushi Bars and Retailers,journal of food protection vo.7 1.no.4 2008 ,p.800-864

CAC (Codex Alimentarius Commission) 2000. Proposed Draft. Code of Practice for Fish and Fishery Products. Alinorm 01/18. Food and Agriculture Organization / World Health Organization, Rome, Italy.

CAC (Codex Alimentarius Commission) 2001. Food Hygiene Basic texts. $2^{\text {nd }}$ ed. Food and Agriculture Organization / World Health Organization, Rome, Italy.

Codex Alimentarius Commission. 2003. Recommended International Code of Practice General Prinsiples of Food Hygiene Rev.4. Food and Agriculture Organization. Rome, Italy.

FDA 2005 ., Steps in Developing Your HACCP Plan The Seafood HACCP Regulation requires that you prepare a HACCP plan for fish and fishery products that you process.

Huss, H.H., P.K. Ben Embarek and A. Reilly 2000. Prevention and control of hazards in seafood. Food Control 11, 149-156

Huss et.al.,2003., Consideration in the application of the HACCP principles to Seafood Production, Assessment and management of seafood safety and quality ,Food and Agriculture organization of the United Nation. Rome, Italy.

Junianto. 2003. Teknik Penanganan Ikan. Jakarta: Penebar Swaday.

Kardarron. 2007., Gambar ikan tuna.www. landbigfish.com. (16 Maret 2010).

Keer M, Paul L, Sylvia A .2002. Effect of Storage Condition on Histamin Formation in Fresh and Canned Tuna. Commision by Food Safety Unit.Dalam www.foodsafety.vic.gov.au. ( 12 April 2008 )

Lehane L, Olley J. 1999. Histamine (Scombroid) Fish Posioning a review in a risk-assessment framework. Canberra: National Office of Animal and Plant health.

NACMCF (National Advisory Committee on Microbiological Criteria for Foods) 1998. Hazard analysis and critical control point principles and application guidelines. Journal of Food Protection 61, 762-775.

Nikijuluw ,2010., Warta Pasar Ikan Edisi Maret, No. 79 ., ISSN 18295576 ,. Direktorat Pemasaran Dalam Negeri,Direktorat Jenderal Pengolahan dan Pemasaran Hasil Perikanan Kementrian Kelautan dan Perikanan (KKP). 
Poernomo, 2010 ., Warta Pasar Ikan Direktorat Pemasaran Dalam Negeri,Direktorat Jenderal Pengolahan dan Pemasaran Hasil Perikanan Kementrian Kelautan dan Perikanan (KKP). Edisi Maret 2010, No. 79 ., ISSN 1829557.

Saanin H. 1984. Taksonomi dan Kunci Identifikasi lkan I \& II. Jakarta : Bina Cipta.

Shalabby. 1996 Signature of Biogenic amines to Food Safety and human Health .Food Rest.Int.29(7): 675-90

Sumner J, Ross T, Ababouch L. 2004. Application of Risk Assessment in the Fish Industry. Food and Agriculture organization of the United Nation.Rome, Italy.

Taylor SL. 1983. Monograph on Histamin Poisoning Codex Alimentarius Commision. Food and Agriculture organization of the United Nation.Rome, Italy.

WHO (World Health Organization) 1996. Guidelines for drinking water quality. $2^{\text {nd }}$ ed. Vol 2. Health criteria and other supporting information. World Health Organization, Geneva, Switzerland. 